\title{
Soy-derived Phosphatidic Acid, Lysophosphatidic acid and Phosphatidylserine are sufficient to induce an increase in mTOR signaling
}

\author{
David M Gundermann ${ }^{1 *}$, Ralf Jäger ${ }^{2}$, Martin Purpura ${ }^{2}$, Troy A Hornberger ${ }^{1}$ \\ From International Society of Sports Nutrition: 10th Annual ISSN Conference and Expo \\ Colorado Springs, CO, USA. 14-15 June 2013
}

\begin{abstract}
Background
A protein kinase called the mechanistic target of rapamycin (mTOR) is a well-known regulator of cellular growth. In fact, several studies have indicated that the kinase activity of mTOR is required for mechanicallyinduced increases in skeletal muscle protein synthesis and hypertrophy. Previous studies have also determined that the lipid messenger phosphatidic acid (PA) plays a critical role in the stimulation of mTOR signaling and, an increase in PA concentration is sufficient for the activation of mTOR signaling. However, the mechanism by which PA stimulates mTOR is currently unknown. A primary target of mTOR includes the phosphorylation of p70 on the threonine 389 residue (P-p70-389), and thus, is a commonly accepted readout for the activation of mTOR. PA can be synthesized from a variety of reactions via multiple reactants. Therefore, the purpose of this study was to compare the effects of various PA precursors on their ability to stimulate mTOR signaling and determine if any other phospholipid species are also capable of stimulating mTOR signaling.
\end{abstract}

\section{Methods}

$\mathrm{C}_{2} \mathrm{C}_{12}$ myoblasts were plated at approximately $30 \%$ confluence and grown for 24 hours in 10\% FBS High Glucose DMEM. Cells were switched to $2 \mathrm{~mL} /$ well serum free high glucose DMEM (no antibiotics) for 16 hours prior to the experiment. Cells were approximately $70 \%$ confluent at the time of the experiment. Cells were then stimulated for 20 minutes with vehicle (Control) or 10,30 or $100 \mu \mathrm{M}$ of soy-derived phosphatidylserine

\footnotetext{
* Correspondence: gundermann@wisc.edu

'Department of Comparative Biosciences, University of Wisconsin, Madison, WI, USA

Full list of author information is available at the end of the article
}

(S-PS, SerinAid, Chemi Nutra, White Bear Lake, MN), phosphatidylinositol (S-PI), phosphatidylethanolamine (S-PE), phosphatidylcholine (S-PC), PA (S-PA, Mediator, Chemi Nutra, White Bear Lake, MN), lysophosphatidic acid (S-LPA), diacylglycerol (DAG), glycerol3-phosphate (G3P), and egg-derived PA (E-PA). Cells were harvested in lysis buffer and subjected to immunoblotting. The ratio of P-p70-389 to total p70 was used as readout for mTOR signaling.

\section{Results}

S-PI, S-PE, S-PC, DAG, and G3P elicited no increase in the ratio of P-p70-389 to total p70 compared to vehicle stimulated cells. In contrast, elevated mTOR signaling was observed at all tested concentrations of S-PS $(529,588$, and $457 \%)$, S-LPA $(649,866$, and 1,132\%), and S-PA (679, 746, and 957\%; $\mathrm{P}<0.05)$. Egg-PA induced an $873 \%$ increase in mTOR signaling with the $100 \mu \mathrm{M}$ dose $(\mathrm{P}<0.05)$, whereas no significant increase was observed with the 10 or $30 \mu \mathrm{M}$ doses.

\section{Conclusions}

S-PA, S-LPA and S-PS are each sufficient to induce an increase in mTOR signaling. Therefore, they may be capable of enhancing the anabolic effects of resistance training and contributing to muscle accretion over time. Furthermore, S-PA is a more potent stimulator of mTOR signaling than PA derived from egg.

\section{Acknowledgements \\ Supported by Chemi Nutra, White Bear Lake, MN, USA.}

\section{Authors' details}

Department of Comparative Biosciences, University of Wisconsin, Madison, WI, USA. ${ }^{2}$ Increnovo LLC, 2138 E Lafayette PI, Milwaukee, WI, USA.

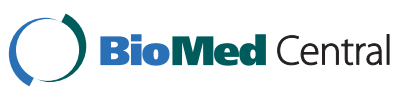

(c) 2013 Gundermann et al; licensee BioMed Central Ltd. This is an Open Access article distributed under the terms of the Creative Commons Attribution License (http://creativecommons.org/licenses/by/2.0), which permits unrestricted use, distribution, and reproduction in any medium, provided the original work is properly cited. 
Published: 6 December 2013

doi:10.1186/1550-2783-10-S1-P7

Cite this article as: Gundermann et al: Soy-derived Phosphatidic Acid, Lysophosphatidic acid and Phosphatidylserine are sufficient to induce an increase in mTOR signaling. Journal of the International Society of Sports Nutrition 2013 10(Suppl 1):P7.

Submit your next manuscript to BioMed Central and take full advantage of:

- Convenient online submission

- Thorough peer review

- No space constraints or color figure charges

- Immediate publication on acceptance

- Inclusion in PubMed, CAS, Scopus and Google Scholar

- Research which is freely available for redistribution

Submit your manuscript at www.biomedcentral.com/submit 